\title{
The Largest Known Maars on Earth, Seward Peninsula, Northwest Alaska
}

\author{
JAMES E. BEGÉT, ${ }^{1}$ DAVID M. HOPKINS ${ }^{1}$ and STEVEN D. CHARRON ${ }^{2}$
}

(Received 23 January 1995; accepted in revised form 5 October 1995)

\begin{abstract}
The Espenberg Maars on the northern Seward Peninsula of Alaska were formed by a series of Pleistocene basaltic eruptions through thick permafrost. The maars were excavated as much as $300 \mathrm{~m}$ into older lithologies; ranging from 4 to $8 \mathrm{~km}$ in diameter, they are the four largest known maars on earth. Hydromagmatic eruptions which derive water from ground ice are evidently extremely explosive. The high heat capacity of ice in permafrost modulates the supply of water interacting with magma during the eruption, producing consistently low coolant-to-fuel ratios in an environment with a sustained, abundant water supply. The Espenberg Maars demonstrate that, under certain conditions, eruptions which involve the interaction of lava and permafrost are powerful enough to produce craters as large as small calderas.
\end{abstract}

Key words: maar, permafrost, arctic, Alaska, hydromagmatic

RÉSUMÉ. Les maars de l'Espenberg situés dans la partie septentrionale de la péninsule Seward en Alaska ont été formés par une série d'éruptions basaltiques datant du pléistocène, à travers une forte épaisseur de pergélisol. Les maars ont été creusés à une profondeur allant jusqu'à $300 \mathrm{~m}$ dans d'anciennes roches; d'un diamètre variant entre 4 et $8 \mathrm{~km}$, ils sont les quatre plus grands maars connus sur Terre. Les éruptions hydromagmatiques qui tirent l'eau de la glace de sol sont, comme on l'a déjà constaté, extrêmement explosives. La grande capacité thermique de la glace dans le pergélisol détermine l'approvisionnement en eau qui interagit avec le magma au cours de l'éruption, donnant régulièrement lieu à un faible rapport refroidissant / combustible dans un environnement où l'eau est constamment abondante. Les maars de l'Espenberg démontrent que, dans certaines conditions, les éruptions qui déclenchent une interaction lave-pergélisol sont suffisamment puissantes pour donner naissance à des cratères de la grandeur de petites calderas.

Mots clés: maar, pergélisol, arctique, Alaska, hydromagmatique

Traduit pour la revue Arctic par Nésida Loyer.

\section{INTRODUCTION}

Maars are shallow but broad craters formed by explosive excavation into older lithologies during phreatomagmatic eruptions. The Espenberg Maars are found on the northernmost Seward Peninsula (Fig. 1), just south of the Arctic Circle, and farther north than any other Late Pleistocene volcanoes in North America (Wood and Kienle, 1990). Because of their high-latitude setting in Alaska, these maar eruptions occurred in an area where permafrost is ca. $100 \mathrm{~m}$ thick.

The presence of basaltic rocks on the northern Seward Peninsula was first noted by Moffitt (1905). Hopkins (1959, 1963) identified extensive Quaternary basaltic lava flows, especially in the Imuruk Lake area of the central Seward Peninsula, and later described the Late Quaternary Espenberg Maars and coeval tephra layers (Hopkins,1988). Radiocarbon dates and tephrochronology, together with relative age estimates based on the degree of erosion and sedimentation in the lake basins, indicate that the Devil Mountain Maar is the youngest, formed ca. 17500 years B.P. (Table 1); South Killeak Maar is $>40000$ years old; North Killeak Maar is somewhat older; and Whitefish Maar may be 100-200 000 years old (Hopkins, 1988; Begét et al., 1991).
Although maars are the second most common volcanic landform after cinder cones (Cas and Wright, 1987), no previous examples have been documented of maars produced by eruptions through permafrost. Here we describe the geomorphology and model the thermodynamic processes that occur during the interaction of magma and permafrost. Such interactions led to highly explosive eruptions and the formation of unusually large maars on the Seward Peninsula of northwest Alaska.

\section{DIMENSIONS OF HYDROVOLCANIC CRATERS AND MAAR LAKES}

The Espenberg Maars consist of four large, separate eruptive craters, each excavated 100-300 m into Pleistocene sediments and lavas. Most of the maars are circular to slightly elliptical in shape, except for the Devil Mountain Maar, which is an irregular composite crater containing North and South Devil Mountain Lakes (Fig. 1). North Devil Mountain Lake $(5.1 \mathrm{~km}$ in diameter) is partly separated from South Devil Mountain Lake (3.4 km diameter) by a small sand spit.

Sequences of bedded surge deposits, airfall lapilli beds,

\footnotetext{
${ }^{1}$ Department of Geology and Geophysics, University of Alaska, Fairbanks, Alaska 99775-0760, U.S.A.

${ }^{2}$ Department of Geology and Geography, University of Massachusetts, Amherst, Massachusetts 01003, U.S.A.

(C) The Arctic Institute of North America
} 


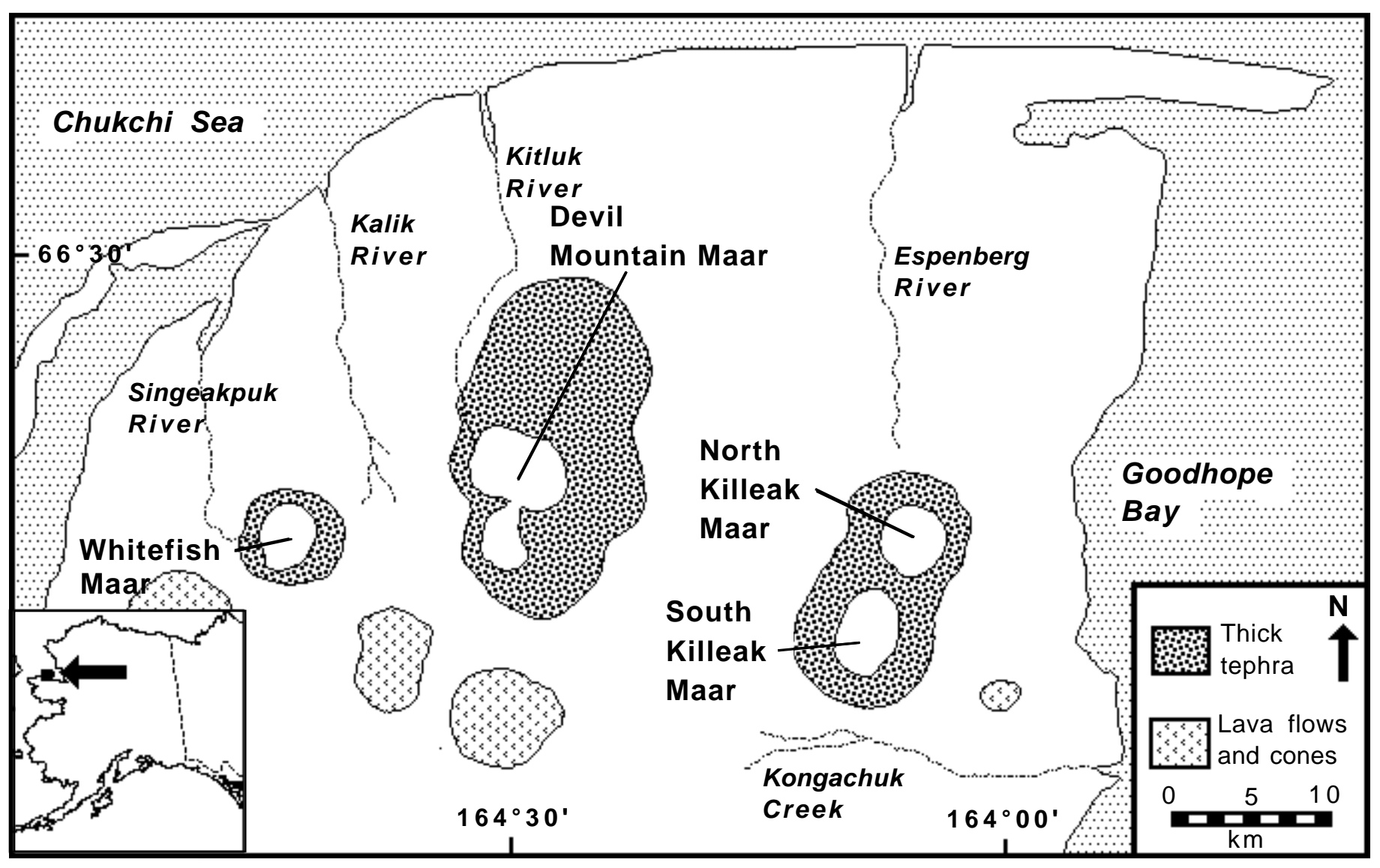

FIG. 1. Location of the Espenberg Maars on the northern Seward Peninsula, Alaska, showing Devil Mountain Maar, Whitefish Maar, North Killeak Maar, and South Killeak Maar. Surrounding each maar is a thick blanket of pyroclastic surge and airfall tephra deposits; the pattern shows the distribution of tephra more than $5 \mathrm{~m}$ thick surrounding each maar.

TABLE 1. Radiocarbon dates on organic material buried by Devil Mountain Lakes Maar tephra, Seward Peninsula, Alaska.

\begin{tabular}{|c|c|c|c|}
\hline $\begin{array}{l}\text { Radiocarbon } \\
\text { Date }\end{array}$ & $\begin{array}{l}\text { Laboratory } \\
\text { Number }\end{array}$ & $\begin{array}{l}\text { Material } \\
\text { Dated }\end{array}$ & Location \\
\hline $16990 \pm 150$ & B-18632 & peat (macrofossil) & Nuglungnugtuk River \\
\hline $17420 \pm 260$ & B-60718 & peat (macrofossil) & Lake Rhonda \\
\hline $17630 \pm 800$ & W-3489 & peat (macrofossil) & Whitefish Thaw Pond \\
\hline $17740 \pm 110$ & B-75731 & peat (macrofossil) & Lumpy Drained Lake \\
\hline $17740 \pm 220$ & B-75529 & peat (macrofossil) & Tempest Lake \\
\hline $17910 \pm 150^{1}$ & B-18549 & detrital twigs & Kiliwooligoruk Creek \\
\hline $16880 \pm 120$ & B-60716 & wood (macrofossil) & Egg Lake \\
\hline $17980 \pm 100$ & B-71983 & sediment & Egg Lake \\
\hline
\end{tabular}

${ }^{1}$ in reworked alluvium

massive pyroclastic flows, and explosion breccia can be traced through many fresh exposures in 10-40 $\mathrm{m}$ high cliffs around the Devil Mountain Lakes Maar (Fig. 2a, 2b). Stratigraphic sections were measured through the volcanic pile at many sites around the lakes, and complex but uninterrupted sequences of plane-bedded and cross-bedded surge deposits, massive explosion breccia, and scoria beds were found. No trace of nonvolcanic sediment or paleosol development was found at any level within the sequence of volcaniclastic sediments (Fig. 2b). Similarly, radiocarbon dates from organic material preserved at numerous sites beneath a widespread tephra deposit on the northern Seward
Peninsula produced by the eruptions of the Devil Mountain Lakes Maar all indicate an age of about 17500 years B.P. (Table 1). The existence of only a single tephra deposit at numerous sites around the maar, the similarity of all radiocarbon dates from beneath the tephra deposits, and the absence of significant stratigraphic breaks in either the distal ash or the proximal volcaniclastic sequence indicate the Devil Mountain Lakes Maar formed during one complex eruptive episode about 17500 years B.P. The crater produced during those eruptions, measured from rim to rim across the maar lake, is $8 \mathrm{~km}$ long by $6 \mathrm{~km}$ wide, as much as $200 \mathrm{~m}$ deep, and covers over $30 \mathrm{~km}^{2}$ (Fig. 1).

The maar craters at North and South Killeak Lakes, located $20 \mathrm{~km}$ east of the Devil Mountain Maar, are 4.0 and 5.0 $\mathrm{km}$ in diameter and ca. 20 and $12 \mathrm{~km}^{2}$ in area, respectively (Fig. 1). Whitefish Maar lies $15 \mathrm{~km}$ west of the Devil Mountain Maar, is $4.3 \mathrm{~km}$ in diameter, and covers $15 \mathrm{~km}^{2}$, although the lake basin has been partly filled by alluvium and other sediments since the eruption. Exposures through proximal hydromagmatic deposits are rare at the older maars, but isolated exposures exist in stream gullies at each older maar, and in each case the absence of paleosols, nonvolcanic sediment, or other stratigraphic breaks suggests each of these maars formed as the result of complex but monogenetic eruptive events.

In comparison to the Espenberg Maars of the Seward 

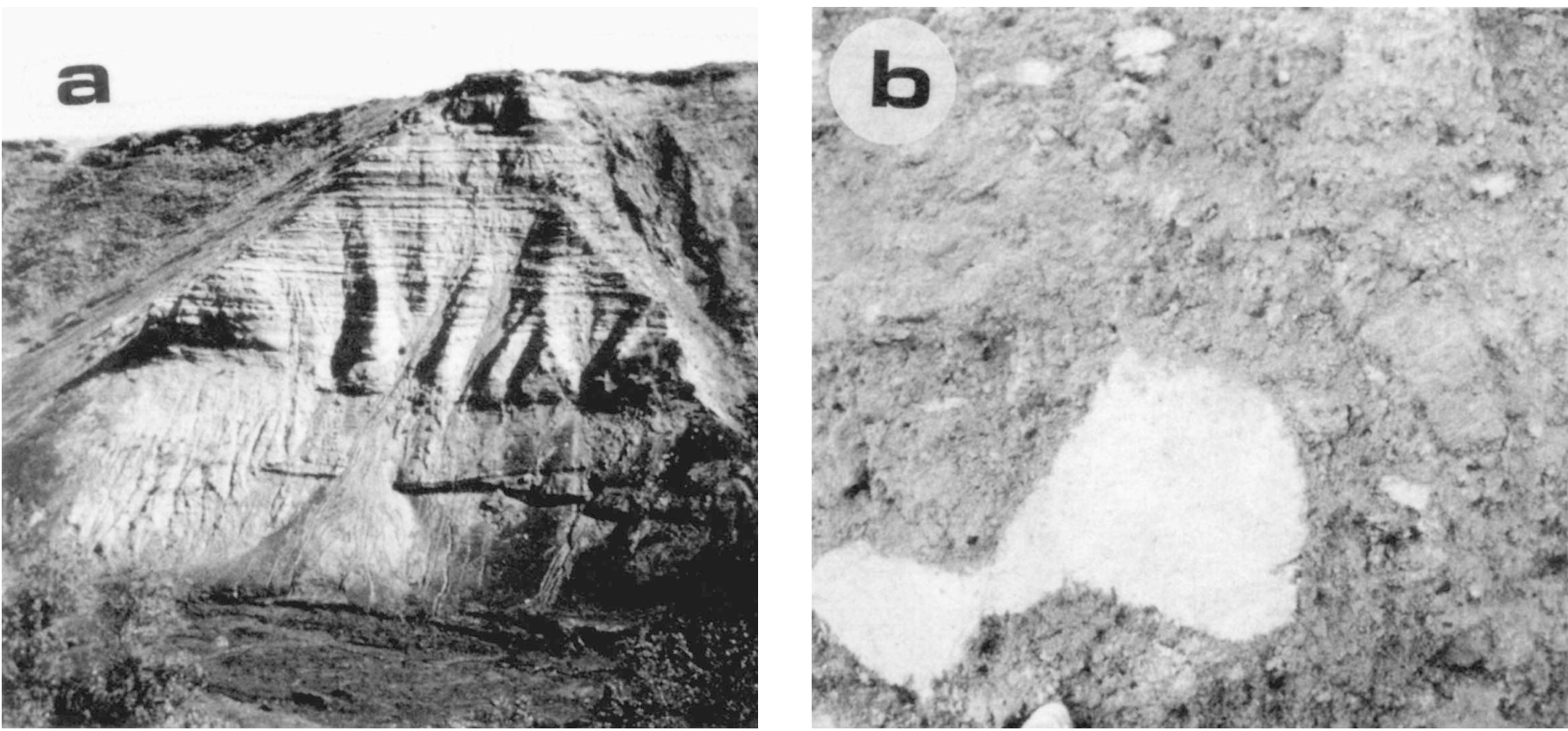

FIG. 2. a) Exposure of volcaniclastic sediments near the southwest shore of North Devil Mountain Lake, showing plane-bedded surges overlying massive pyroclastic flows and explosion breccia. The outcrop is $45 \mathrm{~m}$ high. b) Outcrop of explosion breccia near the eastern shore of South Devil Mountain Lake, containing numerous clasts of unconsolidated sands, peats, and other materials. The dumbell-shaped clast in the lower center of the photograph consists of unconsolidated, bedded medium sand, thought to have been frozen when emplaced. The knife (base of photograph) is $2 \mathrm{~cm}$ across.

Peninsula, virtually all maars at lower latitudes are much smaller. Average diameters of typical maars are only a few hundred to a thousand meters, and cover less than $1 \mathrm{~km}^{2}$ in area (Cas and Wright, 1987). The largest such features previously described are about $3 \mathrm{~km}$ in diameter, with surface areas less than $8 \mathrm{~km}^{2}$ (Fig. 3). The Espenberg Maars are therefore several times larger in diameter than other maars, and an order of magnitude larger in surface area.

The underwater topography of several of the Alaskan maar lakes was studied by depth profiling during the summer of 1992. The lake basins in Devil Mountain Lakes Maar are locally more than $100 \mathrm{~m}$ deep (Fig. 4) and, if we include the height of bedrock cliffs around the lake, the maar craters have been excavated as much as $250 \mathrm{~m}$ into older sediments and lava flows. The maximum water depth at North Killeak Lake is about $25 \mathrm{~m}$, while South Killeak Lake is more than $60 \mathrm{~m}$ deep; but these lakes lie in the bottom of craters excavated $200-250 \mathrm{~m}$ into older basalt lava flows. Whitefish Lake was not profiled, but is much shallower than the other lakes, consistent with its greater age and degree of infilling.

The bottom of the Devil Mountain Lakes Maar is extensively cratered, with at least eight separate depressions visible in the contour data (Fig. 4). These well-defined craters range from $0.1-1 \mathrm{~km}$ in diameter and are 50-100 $\mathrm{m}$ deep. The underwater craters seem to trend north-south in South Devil Mountain Lake, but east-west in North Devil Mountain Lake, paralleling the ellipitical asymmetry of each lake basin. Similar but partly infilled craters are also visible in depth profiles from the somewhat older Killeak Lakes.

We interpret the closed depressions on the floors of the Espenberg maars as small explosion craters, as they are similar in size to typical, small hydromagmatic craters observed elsewhere. These craters evidently mark the sites of explosive activity during the eruption; other explosion craters may have formed earlier in the eruption sequence, only to be obliterated or filled in by later eruptions. Although we are unable to find any published bathymetric data from other maars, we speculate that multiple craters may exist on other maar lake floors. Similar groups of coeval explosion craters have recently been documented at sites like Cerro Xalapaxco in central Mexico, where multiple phreatomagmatic eruptions occurred at a site with an especially abundant water supply (Abrams and Siebe, 1994).

\section{HYDROMAGMATIC ERUPTIVE PROCESSES AT THE ESPENBERG MAARS}

The Espenberg Maars are the first reported example of hydromagmatic eruptions produced by interactions of magma with permafrost (Table 2). The well-documented 1977 Unkinrek Maar eruption in southwest Alaska (Kienle et al., 1980; Self et al., 1980) occurred in an area $1500 \mathrm{~km}$ south of the Espenberg Maars, and outside the southern limits of permafrost in Alaska (Péwé, 1975). Field studies at other high-latitude maars, such as the 1875 Viti Maar in Iceland (Sigurdsson and Sparks, 1978), also found no evidence for permafrost playing a role in the eruption.

The processes involved in the interaction of permafrost and magma at the Espenberg Maars are more than a curiosity, as the unusually large size of these four maars indicates that hydromagmatic eruptions involving permafrost can be significantly more explosive and typically excavate craters larger than those resulting from interactions with surface or 


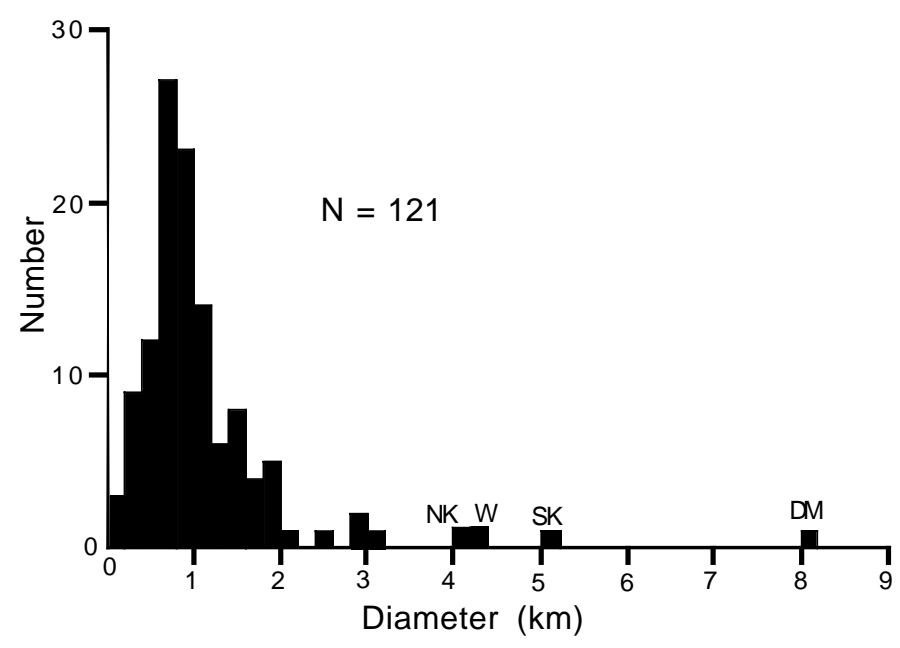

FIG. 3. Histogram of diameters of known maars, showing typical diameters are $1-2 \mathrm{~km}$. The four Espenberg maars $($ Devil Mountain $=$ DM, North Killeak $=$ NK, South Killeak $=$ SK, and Whitefish $=\mathrm{W}$ ) are significantly larger than any previously described maar, and constitute the four largest-known maars on earth. Figure modified from Cas and Wright (1987).

groundwater (Table 2). Massive ground ice and ice wedges occur in surface exposures around the Seward Peninsula today, and disseminated ice is present throughout the frozen sediments and within the fractured basaltic flows which form the substrate in the area of the Espenberg Maars. Data from several drill holes on the northern Seward Peninsula indicate that the ground is currently frozen to depths of as much as $100 \mathrm{~m}$ in this area; permafrost was probably somewhat thicker during the Pleistocene, when the eruptions occurred (Péwé, 1975).

The processes of interaction between lava and water are known to be complex (Sheridan and Wohletz, 1981, 1983). However, the physical and thermodynamic properties of ice differ considerably from those of liquid water, and introduce additional steps and complexity. The thermal conductivity of ice is several orders of magnitude lower than that of lava, so ice in direct contact with lava can insulate deeper ice and restrict melting to the surfaces actually in contact. This is illustrated by the observation that lava flows which traverse glaciers generally do not cause rapid melting of large volumes of snow and ice (Major and Newhall, 1989).

The strong contrast between the heat capacity of basaltic lava, estimated at ca. $0.3 \mathrm{cal} \mathrm{gm}^{-1} \mathrm{deg}^{-1}$ (McBirney, 1993), and that of ice and frozen soil, at $2.3-4.0 \mathrm{cal} \mathrm{gm}^{-1} \mathrm{deg}^{-1}$ (Williams and Smith, 1989), will also tend to inhibit rapid melting of ground ice, as 10 grams of lava must drop a degree in temperature to produce each degree rise in temperature of a gram of frozen sediments. Pleistocene permafrost temperatures at the Espenberg Maars were probably ca. $-7^{\circ}$ to $-40^{\circ} \mathrm{C}$, depending on depth, weather, and the time of year. In addition, the latent heat of fusion of ice is $80 \mathrm{cal} \mathrm{gm}^{-1}$, but the latent heat released as lava solidifies produces only ca. $60 \mathrm{cal} \mathrm{gm}^{-1}$ (McBirney, 1993), further tending to minimize melting during lava-ice interactions. Finally, even after some ground ice has melted, an additional 100 cal must be extracted from the lava to heat each gram of water to $100^{\circ} \mathrm{C}$ before it can flash to

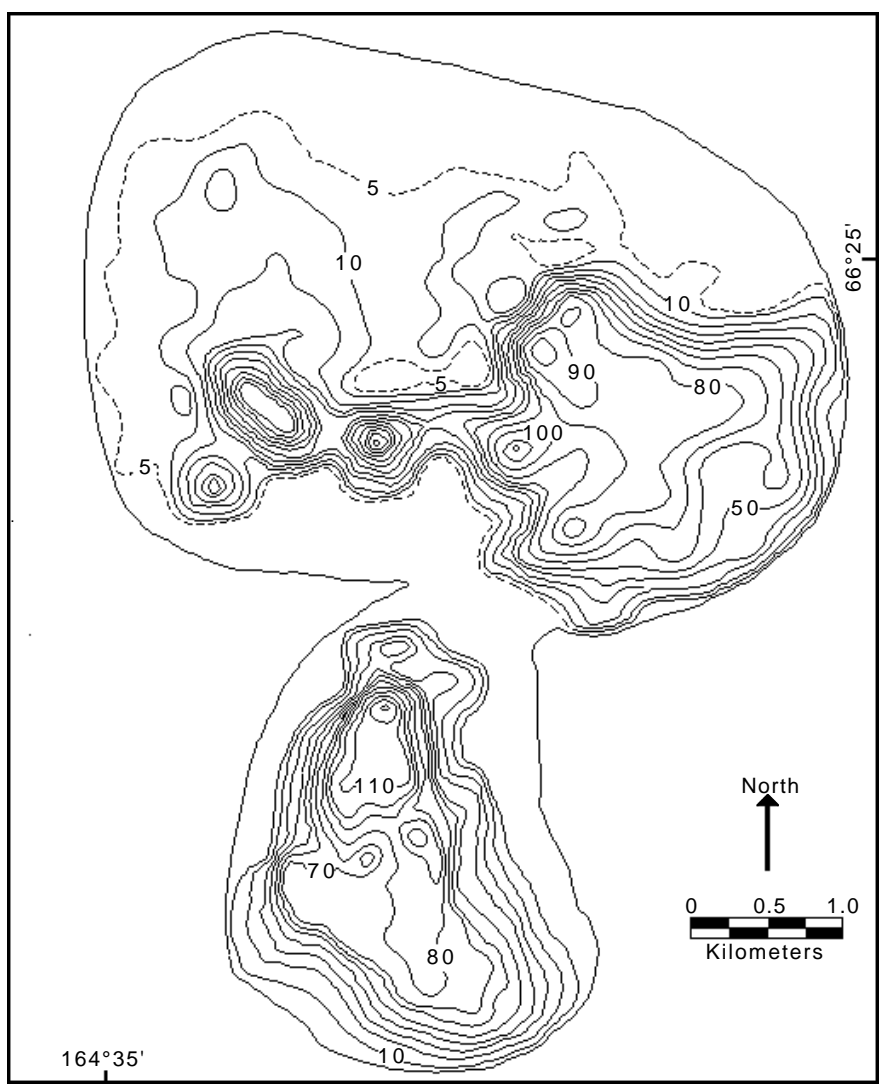

FIG. 4. Bathymetry of Devil Mountain Maar, showing the lake floor. The maar is locally more than $100 \mathrm{~m}$ deep. Small $(0.2-1.0 \mathrm{~km}$ diameter $)$ depressions delineated by concentric, circular topographic lines may be individual craters formed by phreatomagmatic explosions late in the eruption. These craters record excavation of these large maars during numerous hydromagmatic explosive episodes at shallow depths.

TABLE 2. Water sources for selected hydromagmatic eruptions that have produced maars and tuff cones.

\begin{tabular}{llrr}
\hline \hline Water sources & Example & $\begin{array}{l}\text { Crater } \\
\text { diameter (m) }\end{array}$ & $\begin{array}{l}\text { Excavation } \\
\text { Depth (m) }\end{array}$ \\
\hline Maars: & & & \\
$\begin{array}{l}\text { permafrost } \\
\text { ground water } \\
\text { shallow lake }\end{array}$ & Espenberg Maars, Alaska & $4000-8000$ & 300 \\
Taal, Philippines & 300 & $\begin{array}{r}\text { ca. 100 } \\
\text { ca. 50 }\end{array}$ \\
$\begin{array}{l}\text { Tuff Cones: } \\
\text { shallow marine } \\
\text { shallow lake }\end{array}$ & 200 & \\
playa & Pavant Butte, Utah & & 0 \\
\hline \hline
\end{tabular}

steam and phreatic explosions can occur. Altogether, these thermodynamic constraints dictate that about two-to-three times more energy is needed to melt ice in permafrost and bring the meltwater to the boiling point than would be required to boil an equivalent mass of ground water or surface water beginning at ambient surface temperatures.

These physical constraints clearly indicate that ground ice which comes into contact with lava melts and flashes to steam considerably more slowly than an equivalent amount of liquid groundwater. Also, the total amount of liquid water produced by melting of ground ice during an eruption is 
continuously limited by the thermodynamic properties of both permafrost and lava. These constraints occur throughout the course of an eruption, even though abundant ice is present in the frozen sediments.

Sheridan and Wohletz $(1981,1983)$ showed that the explosivity of hydromagmatic eruptions is maximized when water-to-magma ratios are low. Experimental tests suggest that fuel-coolant reactions are most explosive when thermal energy is efficiently transmitted to the coolant, and water and magma mixtures become well mixed and approach thermal equilibrium most completely at ratios of ca. $0.3-0.5$ (Wohletz, 1986). At most maars, highly explosive conditions constitute a transient eruptive phase associated either with initially low supplies of groundwater, or with the exhaustion of available water supplies during the course of the eruption.

In contrast, the intrinsic difficulties of melting ground ice during eruptions through permafrost would tend to produce the low water-to-magma ratios which are associated with high explosivity, while the ubiquitous supply of ice in the frozen sediments would ensure that water is continually available throughout the course of the eruption. The total amount of water generated by melting at any time would most likely be small in relation to the volume of lava in contact with permafrost. Low water-to-magma ratios could theoretically be maintained throughout the course of even prolonged eruptions. Hydromagmatic eruptions through permafrost are therefore likely to be characterized by sustained, highly explosive conditions.

The conditions of abundant total water supply and limited water availability during an eruption are usually mutually exclusive. However, eruptions in areas of continuous permafrost, like that of the ca.100 m thick permafrost layer on the northern Seward Peninsula, may encounter an abundant supply of ice - present throughout the entire area affected by eruptions, bonded into all surface sediments, soil, and rocks, and locally exceeding $50 \%$ by volume-while at the same time the supply of liquid water is limited by thermodynamics.

Lorenz (1986) suggested that maars grow as crater walls collapse into successively deeper and wider conduits. The shapes of North and South Devil Mountain Lakes and the evidence of multiple craters on the floors of the lakes (Fig. 4) indicate that complex vent structures, perhaps controlled by fissures, existed during these arctic eruptions, and influenced the shape of the maar craters. However, these craters also grew as a consequence of landsliding into the vents, as landslide complexes, some more than $1 \mathrm{~km}$ wide, ring the Espenberg Maars today (Fig. 5), and clearly played an important role in the growth of these large maars (Hopkins, 1988). These landslide complexes are delineated today by $1-2 \mathrm{~m}$ high scarps which cut across topographic features, as well as by parallel stream channels and by elongated lakes.

Landslides of high-enthalpy, water-rich debris into vents can produce hydromagmatic explosions (Houghton and Nairn, 1991), and since permafrost is extremely prone to failure during thawing, it is likely that mixtures of frozen debris and high-enthalpy water and steam were introduced into vents by landslides at the Espenberg Maars. These maars therefore

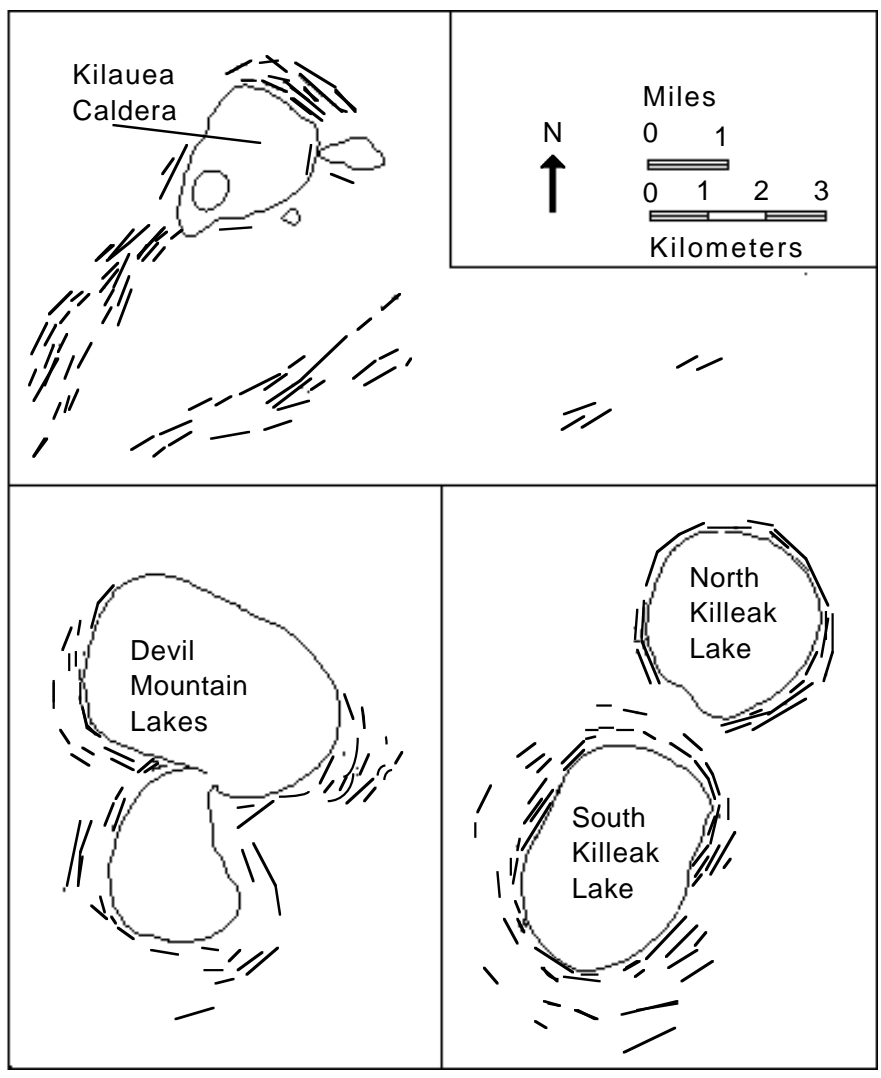

FIG. 5. Devil Mountain Maar, and North and South Killeak Maars, when plotted at the same scale as Kilauea Caldera in Hawaii, show that the Espenberg maars are similar in size or larger than small volcanic calderas. Scarps and concentric fractures around the Alaskan maars (shown by concentric lines) record landslides and other mass movements in the surrounding permafrost, and indicate that these maars grew in part as the result of slope failure and slumping into the maar craters.

grew from a combination of several processes, including the coalescence of several vents during extended eruptions and repeated collapse of landslide debris from the margins of the crater. The landslides contributed to the mixing of blocks of frozen ground with magma, and to the highly explosive character of the eruptions.

Some other unusual eruptive processes may have been important at these high-latitude maars. For instance, the depth of excavation of the maars is similar to but slightly greater than the modern thickness of permafrost. Perhaps this reflects ponding of magma or water that produced explosions at the base of the permafrost during the eruptions. Also, significant quantities of methane and methane hydrate sometimes accumulate under permafrost (Kvenvolden, 1988; Nisbet, 1989); it is conceivable that methane explosions occurred in the course of the eruptions at the Espenberg Maars.

Volcaniclastic sediments surrounding Devil Mountain Maar and the other Espenberg Maars contain evidence of numerous surges and explosions during these hydromagmatic eruptions. Sequences of plane-bedded and cross-bedded surge deposits, Strombolian airfall beds, and explosion breccias are exposed in 10-80 m thick sections which completely surround the lakes (Figs. 2a, 2b). The surge deposits consist of 
blocky, lithic fragments in a sand-sized crystal-lithic matrix. Accretionary lapilli are uncommon, suggesting water contents of the surges were low. Base surges may have swept across the wide platforms, visible in the bathymetric data, that surround the craters in the center of the maar lakes (Fig. 4).

At least two layers of explosion breccia, each 1-5 m thick, are exposed in bluffs on the southwest shoreline of North Devil Mountain Lake, and similar breccias are exposed at other sites around the lakes (Fig. 2a). The clasts in the explosion breccia deposits at Devil Mountain Maar consist of rounded boulders of layered soft clays, silts, sand, bedded coarse sand and pebbles, and peats and partially petrified wood, as well as occasional massive basalt clasts derived from older basalt flows (Hopkins, 1988). The many fragile blocks of soft sediment, ranging from 0.5 to $2 \mathrm{~m}$ in diameter (Fig. 2a), must have been frozen when transported and emplaced. These blocks provide direct evidence of the explosive interaction of magma and permafrost during these eruptions.

\section{FORMATION OF CALDERA-SIZED CRATERS BY HYDROMAGMATIC ERUPTIONS THROUGH PERMAFROST}

A caldera is defined as a "large volcanic depression, more or less circular or cirque-like in form, the diameter of which is many times greater than that of the included vent or vents, no matter what the steepness of the walls or form of the floor" (Bates and Jackson, 1980:89; cf. Williams, 1941). A diameter of at least $2-3 \mathrm{~km}$ is usually taken as the minimum size for a caldera. No single causal mechanism is dictated by this definition, which is found in virtually all contemporary volcanology and geomorphology textbooks, as well as in geologic dictionaries and glossaries published by geologic societies. It is occasionally suggested that the term caldera be restricted only to large collapse craters formed by ignimbrite eruption, but in the strict sense this is incorrect and inconsistent with general usage in the geologic and volcanologic communities. For example, well-defined calderas exist at Kilauea and Mauna Loa (Carr and Greeley, 1980), at sites clearly associated with effusive rather than explosive ignimbrite eruptions. Reviews by Williams (1941), Yokoyama(1960), Smith and Bailey (1968), Williams and McBirney (1979), and Walker (1984) all discuss a variety of caldera-forming processes together with representative examples of calderas.

As shown in this paper, hydromagmatic eruptions through permafrost on the northern Seward Peninsula of Alaska have repeatedly excavated caldera-sized craters, forming the largest known maars on earth (Begét and Mann, 1992). The Devil Mountain Lakes Maar is similar in diameter to the classic Crater Lake caldera in Oregon (Williams, 1941), and all of the Espenberg Maars are larger than well-known small calderas, such as the summit calderas at Kilauea and Mauna Loa in Hawaii or Katmai Volcano in Alaska (Fig. 5). The four Espenberg craters are therefore examples of caldera-sized maars, formed by explosive excavation and coalescence of smaller craters during complex but monogenetic eruptions.

While the Espenberg maars are currently the only known examples of caldera-sized maars formed by permafrostmagma interactions, it is important to note that broadly similar processes may operate during hydromagmatic eruptions at maars at lower latitudes. For instance, Wohletz and Heiken (1992:92) suggested that caldera structures at the Baccano caldera in Italy "appear to represent the coalescence of several maar vents that eventually collapsed together to form a single caldera." The Baccano caldera is about $3 \mathrm{~km}$ in diameter (Funiciello et al., 1979).

Lorenz (1986) suggested that maars form when hydromagmatic explosions "ream out" funnel-shaped vents that had become backfilled with ejecta and wall-collapse material. His model closely resembles the purely magmatic process hypothesized to have formed some Japanese calderas (Yokoyama, 1958, 1960), albeit on a smaller scale. The large craters of the Espenberg Maars are not simple, single vents, but evidently formed when multiple smaller craters coalesced. The presence of permafrost apparently tends to produce this type of eruption, as each of the four Espenberg Maars of arctic Alaska records a sustained, highly explosive, hydromagmatic eruption which produced a calderasized crater.

Although similar maars have not been described from other areas of the world, it seems likely that other examples of unusually large maar craters exist. Such large maar craters, formed by interaction of permafrost and magma, would necessarily be restricted to high-latitude areas in the Arctic or Antarctic, or to high-elevation areas like the Tibetan plateau, or to mid-latitude areas where Pleistocene permafrost temporarily existed.

\section{SUMMARY AND CONCLUSIONS}

Devil Mountain Lakes Maar on the northern Seward Peninsula is the largest known maar on earth, and South Killeak, North Killeak, and Whitefish Maars are also larger than any previously described maars on earth. The Espenberg Maars were formed by highly explosive hydromagmatic eruptions through permafrost. The explosivity of hydromagmatic eruptions, like other fuel-coolant reactions, is quite sensitive to the ratio of the components. The thermodynamic properties of ice, water, and lava constrain the rate at which water can be produced by melting. The low thermal conductivity, high heat capacity, and high latent heat of fusion of ground ice would tend to produce low water-tomagma ratios during eruptions through ground ice, leading to highly explosive conditions. The ubiquitous presence of thick ground ice in the perennially frozen ground would provide a continuous source of water throughout the course of even a prolonged eruption.

The four Espenberg Maars are similar in size to or larger than small calderas like those at Kilauea, Katmai, and Crater Lake. Multiple small craters on the lake floors, revealed by bathymetric surveys, indicate that the maars were formed by 
the coalescence of multiple vents. Landsliding of frozen sediment from the margins of the craters played an important role in the growth of these unusually large maars. Radiocarbon dating and stratigraphic studies suggest that these maar craters formed during a series of complex but monogenetic eruptions. Hydromagmatic eruptions through permafrost can, in certain cases, produce caldera-sized craters by shallow, explosive excavation of older lithologies.

\section{ACKNOWLEDGEMENTS}

We are grateful to the Bering Land Bridge National Park and the National Park Service for providing financial and logistic support for our work at the Espenberg Maars. Support for Begét was also received from the Division of Polar Programs of the National Science Foundation and the Alaska Volcano Observatory, a joint operation of the U.S. Geological Survey, the University of Alaska, and the Division of Geological and Geophysical Surveys of the State of Alaska. Dr. Kenneth Wohletz reviewed an early version of this manuscript. Patricia Craw, Stephen Moffatt, and Tim Tannenbaum ably provided assistance to the field parties, and Dr. Mary Edwards, Dr. Dan Mann, Vickie Goethchus and Claudi Hoefle made helpful suggestions during the fieldwork. Buck Maxon of Arctic Air Guides provided air taxi service from Kotzebue to the Espenberg Maar lakes and back.

\section{REFERENCES}

ABRAMS, M.J., and SIEBE, C. 1994. Cerro Xalapaxco: An unusual tuff cone with multiple explosion craters, in central Mexico (Puebla). Journal of Volcanology and Geothermal Research 63:183-199.

BATES, R.L., and JACKSON, J.A. 1980. Glossary of geology. Second edition. Falls Church, Virginia: American Geological Institute. $751 \mathrm{p}$.

BEGÉT, J., and MANN, D. 1992. “Caldera” formation by unusually large phreatomagmatic eruptions through permafrost in arctic Alaska. Eos 73:636.

BEGÉT, J., MASON, O., and ANDERSON, P. 1991. Age and extent of the ca. 3400 BP Aniakchak tephra. The Holocene 2:117-123.

CARR, M.H., and GREELEY, R. 1980. Volcanic features of Hawaii. Washington, D.C.: National Aeronautics and Space Administration. 211 p.

CAS, R.A.F., and WRIGHT, J.V. 1987. Volcanic successions: Modern and ancient. London: Allen and Unwin. 528 p.

FUNICIELlO, R., PAROTTO, M., MARIOTTI, G., PREITE MARTINEZ, M., and TECCE, F. 1979. Geology, mineralogy, and stable isotope geochemistry of the Cesano geothermal field (Sabatini Mountains volcanic system, northern Latium, Italy). Geothermics 8:44-73.

HOPKINS, D.M. 1959. History of Imuruk Lake, Seward Peninsula, Alaska. U.S. Geological Survey Bulletin 981. 54 p.

1963. Geology of the Imuruk Lake area, Seward Peninsula, Alaska. U.S. Geological Survey Bulletin 1141-C. 21 p.
1988. The Espenberg Maars: A record of explosive volcanic activity in the Devil Mountain-Cape Espenberg area, Seward Peninsula, Alaska. In: Schaaf, J., ed. The Bering Land Bridge: An archeological survey. Nome, Alaska: U.S. Park Service. 188-247.

HOUGHTON, B.F., and NAIRN, I.A. 1991. The 1976-1982 Strombolian and phreatomagmatic eruptions of White Island, New Zealand: Eruptive and depositional mechanisms at a "wet" volcano. Bulletin of Volcanology 54:25-49.

KIENLE, J., KYLE, P.R., SELF, S., MOTYKA, R.J., and LORENZ, V. 1980. Ukinrek Maars, Alaska. I. April 1977 eruption sequence, petrology, and tectonic setting. Journal of Volcanology and Geothermal Research 7:11-37.

KVENVOLDEN, K.A. 1988. Methane hydrates and global climate. Global Biogeochemical Cycles 2:221-229.

LORENZ, V. 1986. On the formation of maars and diatremes and its relevance to the formation of tuff rings. Bulletin of Volcanology 48:265-274.

MAJOR, J., and NEWHALL, C. 1989. Snow and ice perturbation during historical volcanic eruptions and the formation of lahars and floods. Bulletin of Volcanology 52:1-27.

McBIRNEY, A.R. 1993. Igneous petrology. Second edition. Boston: Jones and Bartlett. 508 p.

MOFFITT, F.H. 1905. The Fairhaven gold placers, Seward Peninsula, Alaska. U.S. Geological Survey Bulletin 247. 203 p.

NISBET, E.G. 1989. Some northern sources of atmospheric methane: Production, history, and future implications. Canadian Journal of Earth Sciences 26:1603-1611.

PÉWÉ, T.L. 1975. Quaternary geology of Alaska. U.S. Geological Survey Professional Paper 835. 207 p.

SELF, S., KIENLE, J., and HUOT, J.P. 1980. Ukinrek Maars, Alaska. II. Deposits and formation of the 1977 craters. Journal of Volcanology and Geothermal Research 7:39-65.

SHERIDAN, M.F., and WOHLETZ, K.H. 1981. Hydrovolcanic exposions I. The systematics of water-pyroclast equilibration. Science 212:1387-1389.

SHERIDAN, M.F., and WOHLETZ, K H. 1983. Hydrovolcanism: Basic considerations and review. Journal of Volcanology and Geothermal Research 17:1-29.

SIGURDSSON, H., and SPARKS, S. 1978. Rifting episode in North Iceland in 1874-1875 and the eruptions of Askja and Sveinagja. Bulletin of Volcanology 41:149-167.

SMITH, R.L., and BAILEY, R.A. 1968. Resurgent cauldrons. Geological Society of America Memoir 116:613-662.

WALKER, G.P.L. 1984. Downsag Calderas, ring faults, caldera sizes, and incremental caldera growth. Journal of Geophysical Research 89:8407-8416.

WILLIAMS, H. 1941. Calderas and their origin. Bulletin of the Department of Geological Sciences, University of California, Berkeley 25:239-346.

WILLIAMS, H., and McBIRNEY, A.R. 1979. Volcanology. San Francisco: Freeman and Cooper. 367 p.

WILLIAMS, P.J., and SMITH, M.W. 1989. The frozen earth: Fundamentals of geocryology. Cambridge: Cambridge University Press. 306 p.

WOHLETZ, K.H. 1986. Explosive magma-water interactions: Thermodynamics, explosion mechanisms, and field studies. Bulletin of Volcanology 48:245-264. 
WOHLETZ, K.H., and HEIKEN, G. 1992. Volcanology and geothermal energy. Berkeley: California University Press. 432 p. WOOD, C.A., and KIENLE, J. 1990. Volcanoes of North America. Cambridge: Cambridge University Press. 354 p.
YOKOYAMA, I.1958. Gravity survey on Kuttyaro Caldera lake. Journal of Physics of the Earth 17:75-79.

. 1960. The subsurface structure of Oshima volcano, Izu. Journal of Physics of the Earth 18:55-68. 